\title{
Opinions from an inquiry panel
}

The members of the panel at Tufts University that investigated the Cellarticle of which Dr Thereza Imanishi-Kari was the chief author respond to Dr Margot O'Toole's statement.

Doctor Margot O'Toole's response to the Office of Scientific Integrity (OSI), reprinted in part in Nature $(351,180 ; 1991)$, requires comment.

Early in May 1986, Dr O'Toole asked us to look into a potential controversy between herself and her postdoctoral adviser at the Massachusetts Institute of Technology, Dr Thereza Imanishi-Kari. We were not asked to, nor did we, investigate possible fraud. We considered that we were all friends and colleagues. Although we suggested that she pursue these issues with Dr Baltimore and other senior officials at MIT, she preferred at the time to have us resolve this scientific controversy so that she would not be directly involved.

Dr O'Toole made three claims: data in the laboratory records showed that a normal mouse expressed a high frequency of transgene-like idiotype; the Bet-1 reagent used was not as specific as claimed; and early sampling of transgenic mouse hybridoma supernatants led to an underestimation of the amount of transgene-encoded antibody. She felt that these problems raised doubts about the correctness of the conclusions of the Cell paper.

At a meeting with Dr Imanishi-Kari, we viewed data that resolved all three issues. A particularly troubling issue - the data $\mathrm{Dr}$ $O$ 'Toole brought to us indicating that a "normal" mouse produced a high frequency of transgene idiotype positive hybridomas was dealt with conclusively by evidence that the mouse in question was a transgenic littermate.

We also reviewed data from radioimmunoassays of Table 2 clones. Although she now writes that she can "attest to the falsity of this claim", Dr O'Toole was not present at this meeting and cannot provide evidence in relation to it. The need to review these data arose from Dr O'Toole's concern that Table 2 hybridoma wells had been sampled too early. When we raised this issue with Dr Imanishi-Kari, she said that Table 2 data were derived from uncloned wells, but the hybridomas had been cloned and their antibodies characterized. She said many of the hybridomas produced idiotype positive antibodies lacking the transgene encoded allotype. We asked if we could see the data. She asked if we didn't trust her. We were silent, and she began to cry as she brought out the data for us to examine. Our examination of the records convinced us that the necessary data existed and that Dr O'Toole's concerns could be answered. Contrary to the implication of her current statement, these two issues (and the Bet-1 questions) were resolved to our satisfaction.

About a week after the meeting with $\mathrm{Dr}$ Imanishi-Kari, Dr O'Toole told us that she now believed the conclusions of the paper were completely wrong. We arranged a second meeting with Dr Imanishi-Kari.

Dr O'Toole currently claims that at the second meeting, also in May 1986, attended by Drs Imanishi-Kari, O'Toole, Huber and Wortis, "[Dr Imanishi-Kari] candidly admitted that certain crucial experiments described in the paper had not even been performed and that experiments that had been performed had not yielded the results claimed." This is simply not true. Dr Imanishi-Kari repeated a statement she had made previously, namely, that the hybridomas from Table 3 were isotyped; not those in Table 2 as written in the Cell paper (a correction that has been published). There were absolutely no statements made that hybridomas of Table 2 wells were never cloned and radioimmunoassays on the antibodies of such clones never performed.

Dr O'Toole did not raise with us the issue of the failure to clone and characterize hybridomas from Table 2 wells. Corroboration of our view of these events can be found in $\mathrm{Dr}$ O'Toole's memo to Dr Eisen, written within two weeks of our second meeting, as it does not refer to the cloning of Table 2 clones or the RIA analysis of their antibodies as issues. Thus there is no basis for confusion about the matters we dealt with and the current allegations of the OSI. Dr O'Toole's Nature statement, which suggests that the questions she raised to us in 1986 correspond to the crucial evidence in the current OSI draft report, is incorrect.

The focus of the second meeting with $\mathrm{Dr}$ Imanishi-Kari was data arising from transgenic mouse hybridomas that produced IgG and $\operatorname{IgA}$ antibodies which were idiotype positive. At the close of the meeting, Dr Imanishi-Kari said to Dr O'Toole (in these, or similar words), "if you want to believe that the data can be explained on the basis of hybrid formation between $\gamma$ and $\mu$ chains, where the amount of $\mu$ message is undetectable on Northerns and where you postulate an insensitivity of the Bet-1 (anti- $\mu$ ) reagent, you are free to believe." Whereupon Dr O'Toole stood up and said, "I'm satisfied," and offered to shake hands with Dr ImanishiKari. There was absolutely no mention of a retraction.

Dr O'Toole's current statement in Nature restates her view. "Low-level production of the transgene could explain why the hybridomas were positive for the idiotype of the transgene."
We did not tell Dr O'Toole that the paper "would be retracted" nor did we agree that it should. We did not tell Dr O'Toole that "the protection of careers must take precedence over scientific accuracy." We never "slandered" or "libelled" Dr O'Toole.

BRIGITTE T. HUBER

Associate Professor

Tufts University School of Medicine

ROBERT T. WOODLAND Associate Professor

University of Massachusetts

School of Medicine

Henry H. Wortis Professor

Tufts University School of Medicine

I was Margot O'Toole's thesis adviser and maintained a sustained friendship with her. I had every reason to take her concerns seriously and to be supportive of her efforts to resolve scientific questions. In the end I disagreed with her assessment of the science. Different opinions are neither slanders nor libels, and I find it especially painful to hear my opionions so characterized by my first graduate student.

Henry H. Wortis

Dr O'Toole approached me with her disturbing findings because she trusted me as a friend and respected me as a scientist. I had served on her thesis committee and had maintained contact with her during her postdoctoral years. I considered her allegations seriously and reviewed her charges to the best of my abilities. I could detect no evidence of fraud in the material I reviewed. The fact that we disagreed in our interpretation of the data is no justification for impugning my honesty in evaluating it. I acted conscientiously, as a responsible scientist, with a commitment to science, and above all, out of friendship towards $\mathrm{Dr}$ O'Toole. In return, she has misrepresented my statements and deeds to the point where I now feel that she has defamed my scientific and personal reputation.

BrigitTe T. HUBER

Although not personally accused by $\mathrm{Dr}$ O'Toole of slander and libel, I find offensive her statement that I falsely reported what I had seen during the data analysis. It is telling that the one constant to emerge from this unhappy episode is that anyone who has disagreed with Dr O'Toole's analysis of the scientific issues has been accused of either incompetence or deceit. Unfortunately, it is unlikely that the acrimony in this case will be soon reduced to a level where the facts can emerge. 